Nama: Stevania Vorensia Wijaya

Nrp: 130218021

Kelas: A

\title{
The implementation of Good Corporate Governance (GCG) in companies when the Global Economy is uncertain.
}

\author{
A. Z. Tayibnapis \& L. E. Wuryaningsih
}

\section{Review}

In 2018, various efforts were made to increase the ease of doing business in Indonesia. Where in 2018 Indonesia was still stuck with exports and imports which had continued to decline since 2015. The World Bank also stated that in terms of ease of doing business in Indonesia, it was ranked 73 out of 190 countries in 2018. In 2020 all entrepreneurs in Indonesia are required to continue to do business. in creating new innovations and creating verified in order to survive with existing competition.

The fact that is found in Indonesia itself is that there are still many business actors who are confused about making new innovations in order to survive in the global economic condition. Business actors have taken various ways to show their respective advantages, but not many of them have failed due to the global economic disruption. Business ventures are faced with a rapidly changing global competitive environment, so that this makes companies unable to get certainty in doing business as well as advances in digital technology, the emergence of new markets, and changing socio-political conditions.

By looking at the existing conditions, and several companies that did the company but failed, so that company management has the desire to create a system and method of corporate governance with the aim of directing and controlling the direction of the company. Company management implements Good Corporate Governance (GCG) with the definition of a set of rules that can regulate, supervise and manage the relationship between company managers and stakeholders who have an interest in the company to increase the value of the company and the market.

With this, the company management implements GCG which has quality in order to create added value and achieve sustainable business success (Effendi 2009). The advantage of implementing corporate GCG will benefit the company culture, ensuring the establishment, an 
effective audit system, extensive information, and controlling risks. By implementing GCG directly, it is expected that it can fulfill 3 dimensions, namely, performance, compliance and conformity. Properly implemented GCG will build awareness, apply GCG standards, expand the dissemination of the code of conduct, GCG assessment, transparency, and carry out action plans.

In addition to implementing GCG within the company, the company must also pay attention to its human resources or employees by requiring a clear framework with the aim of its organizational structure being more focused and clear. If the company does not have human resources or employees, what the company does will be in vain. With the development of digital technology today, companies are certainly looking for human resources or employees who have more knowledge about information technology, which is where the company will take advantage of this by doing digital marketing.

With the development of digital technology in Indonesia, of course, it also requires company leaders to have more abilities about facing change and also strive to survive, make developments and add significant value to all stakeholders in the company. Company leaders are also required to be able to withstand any changes, such as times of volatility, uncertainty, complexity and ambiguity (VUCA). And some of the challenges that occur can also come from internal and external companies.

Examples of companies that have succeeded in carrying out business transformation and application of human resources are Bank BNI and PT. Hartono Plantation Indonesia. BNI has transformed its business by creating several digital products such as digital loans, mobile banking, applications with payments using QR codes, and chat banking. Meanwhile, the company PT. Hartono Plantation Indonesia itself carries out business transformations such as changing annual crops to crops on a seasonal basis, project development, changing fashion investment to operational, administration to strategic, using a planning basis, implementing modern organizations, creating agricultural industries, turning supply into demand, and being innovators.

In implementing the transformation, change must comply with the basic principles of GCG such as transparency, responsibility, fairness, accountability, and independence and also apply important guidelines such as trade in goods and services, implementation of GCG standards, internal control, ethics, whistleblowing and minimizing risk. that will likely happen.

An example of an Indonesian company that implements GCG well, such as Bank 
Sinarmas, which manages good governance by fully committing itself to implementing the principles of corporate governance in every activity to achieve company goals, namely being trusted by customers and employees so that they can grow continuously, good.

An example of one of the governance policies implemented by Bank Sinarmas is Risk Management in which there are strategies, organizations, procedures and policies and methodologies so as to ensure that the risks faced by Bank Sinarmas can be controlled, observed, recognized and measured appropriately. Bank Sinarmas carries out business transformation using digital technology such as m-banking, so that customers can make payment transactions, transfers, make e-wallet payments and so on through an m-banking application. So that it will also make it easier for customers to carry out transaction activities.

And other policies implemented by Bank Sinarmas are code of ethics policies and guidelines in behavior, code of ethics policies and code of conduct explaining various principles, regulations, and policies in regulating activities contained within the company as well as the code of ethics and guidelines for this behavior. regulate the organization, Management, Directors, Commissioners, and Employees so that they have a clear direction, and these guidelines also apply to any party that cooperates with Bank Sinarmas.

\section{Reference}

Wuryaningsih, A. Z., \& Gora, R. (2019). Companies in Indonesia in the vortex of global economic disruption. Education and Humanities Research 